\title{
Environmental and genetic variation of isoflavone content of soybean seeds grown in Brazil
}

\author{
Mercedes Concórdia Carrão-Panizzi(1), Mark Berhow(2), José Marcos Gontijo Mandarino(1) \\ and Maria Cristina Neves de Oliveira(1)
}

\begin{abstract}
(1)Embrapa Soja, Rodovia Carlos João Strass, Distrito de Warta, CEP 86001-970 Londrina, PR, Brazil. E-mail: mercedes@cnpso.embrapa.br, jmarcos@cnpso.embrapa.br, mcno@cnpso.embrapa.br (2)United States Department of Agriculture, Agricultural Research Service, National Center for Agricultural Utilization Research, Peoria, IL, USA, 61604. E-mail: mark.berhow@ars.usda.gov
\end{abstract}

\begin{abstract}
The objective of this work was to evaluate isoflavone concentrations in seeds of different Brazilian soybean cultivars grown in a range of locations and environmental conditions in Brazil. Seeds of 233 cultivars grown in Ponta Grossa, PR, Brazil, during the 2001/2002 soybean season, and of 22 cultivars sown in different locations of Brazilian Northeast, Southeast on South regions were analyzed for total isoflavones, including daidzin, glycitin, genistin and acetylgenistin. The total isoflavones ranged from $12 \mathrm{mg} 100 \mathrm{~g} \mathrm{~g}^{-1}$ (cv. Embrapa 48) to $461 \mathrm{mg} 100 \mathrm{~g} \mathrm{~g}^{-1}$ (cv. CS 305) among the 233 cultivars grown in Ponta Grossa, and the differences among them are due to genetic effects since all cultivars were grown and collected at the same locatation and year. This is an indication of the possibility of breeding for isoflavone content. Differences in isoflavone content observed in the cultivars grown in different locations permit the selection of locations for optimum isoflavone content (low or high), depending on the uses of soybean. In the Northeast region $\left(5-8^{\circ} \mathrm{S}\right)$, higher concentrations of total isoflavones were observed at São Raimundo das Mangabeiras (232 mg $100 \mathrm{~g}^{-1}$ ) and Tasso Fragoso

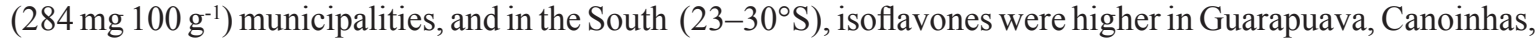
Vacaria and Campos Novos municipalities, ranging from 130 to $409 \mathrm{mg} 100 \mathrm{~g}^{-1}$.
\end{abstract}

Index terms: Glycine max, isoflavones, sowing location, soybean grains, soybean cultivars, soyfood.

\section{Variação genética e ambiental no teor de isoflavonas de sementes de soja cultivada no Brasil}

Resumo - O objetivo deste trabalho foi avaliar concentrações de isoflavonas nas sementes de diferentes cultivares brasileiras de soja cultivadas numa amplitude de condições ambientais e de locais no Brasil. Sementes de 233 cultivares semeadas em Ponta Grossa, PR, na safra de 2001/2002, e sementes de 22 cultivares plantadas em diferentes locais das regiões Nordeste, Sudeste e Sul foram analisadas quanto ao teor total de isoflavonas, incluindo daidzina, glicitina, genistina e acetilgenistina. $O$ total de isoflavonas variou entre $12 \mathrm{mg} 100 \mathrm{~g} \mathrm{~g}^{-1}$ (cv. Embrapa 48) e $461 \mathrm{mg} 100 \mathrm{~g} \mathrm{~g}^{-1}$ (cv. CS 305) entre as 233 cultivares plantadas em Ponta Grossa, e essas diferenças são devidas aos efeitos genéticos, pois todas foram cultivadas e colhidas no mesmo local e ano. Isso indica que há possibilidade de melhoramento genético para o teor de isoflavonas. Diferenças no teor de isoflavonas observadas nas cultivares plantadas nos diferentes locais de semeadura permitem selecionar locais segundo a concentração ótima de isoflavonas (reduzida ou alta), dependendo do uso da soja. No Nordeste $\left(5-8^{\circ} \mathrm{S}\right)$, concentrações mais altas de isoflavonas totais foram observadas nos municípios São Raimundo das Mangabeiras (232 mg $100 \mathrm{~g} \mathrm{~g}^{-1}$ ) e Tasso Fragoso (284 mg $\left.100 \mathrm{~g}^{-1}\right)$. No Sul $\left(23-30^{\circ} \mathrm{S}\right)$, as concentrações de isoflavonas foram maiores nos municípios Guarapuava, Canoinhas, Vacaria e Campos Novos, com amplitude de 130 a 409 mg $100 \mathrm{~g} \mathrm{~g}^{-1}$.

Termos para indexação: Glycine max, isoflavonas, local de semeadura, grãos de soja, cultivares de soja, alimento derivado de soja.

\section{Introduction}

Three structurally distinct isoflavones (daidzein, genistein, and glycitein) are accumulated in soybean seeds as their acylated 7-O-glycoside forms (daidzin, genistin, and glycitin) (MacLeod \& Ames, 1988). The 6-O-malonyl derivatives of these glucosides have been reported by Kudou et al. (1991) as the predominant form present in intact soybean seeds. The malonyl isoflavones are heat labile, and easily converted to the corresponding glycosides and aglycones when submitted to heat (Kudou et al., 1991).

Several studies indicate that genetic variability affects seed isoflavone content of soybean cultivars, and isoflavone content variations can also be affected by annual changes in environmental conditions 
from different locations. Air temperature during the seed-filling period is the most critical environmental factor affecting the final isoflavone concentration. Other factors that affect isoflavones are variations in temperature - both levels and length of time at high or low temperatures -, humidity, light intensity, rainfall - duration and number of rainy days -, and physical damage caused by insects and diseases (Wang \& Murphy, 1994; Tsukamoto et al., 1995, 2001; Carrão-Panizzi et al., 1998; Daydé et al., 2004).

Soybeans grown at low latitudes, generally with higher average temperatures, tend to have relatively lower isoflavone content. The average isoflavone content of Brazilian soybean cultivars is of about $150 \mathrm{mg} 100 \mathrm{~g}^{-1}$, whereas for American soybeans it is $200 \mathrm{mg} 100 \mathrm{~g}^{-1}$, while soybean grown in Japan and Canada have higher concentrations (450 and $550 \mathrm{mg} 100 \mathrm{~g}^{-1}$ respectively) (Tsukamoto et al., 2001). Although average isoflavone concentrations of Brazilian soybeans are relatively low (Carrão-Panizzi et al., 1996), they vary considerably among cultivars (Silva et al., 2009) and in cultivars grown at different locations over the years. A range of 227 to $105 \mathrm{mg} 100 \mathrm{~g}^{-1}$ was observed for the same cultivar (IAS 5) grown, respectively, in a location with low (Vacaria, $\mathrm{RS}, 19^{\circ} \mathrm{C}$ ), and high (Palotina, $\mathrm{PR}, 24^{\circ} \mathrm{C}$ ) average air temperatures during the seed-filling months (Carrão-Panizzi et al., 1999). Daydé et al. (2004) found that low temperatures coupled with late precipitation (rain or irrigation) increased isoflavone concentrations.

Isoflavones in the diet may have effects on the health of humans, through their antioxidant and estrogenic activities, and a wide spectrum of pharmacological properties (Messina, 1999). Isoflavones are also reported as influencing the development and remediation of some of the chronic diseases associated with aging, such as osteoporosis, cognitive disfunction, coronary heart disease and cancer (Messina, 1999). They also have an effective antixenotic, antioxidant and antibiotic action in mammalian systems (Graham, 1991).

Much research is underway with soybean and its isoflavones regarding human health issues. In order to certify isoflavone content and composition in dietary supplements or soyfoods, the qualitative determination of these compounds in various soybean cultivars grown under different environmental conditions is needed.

The objective of this work was to evaluate isoflavone concentrations in seeds of different Brazilian soybean cultivars, verifying genetic differences and effects of different sowing locations in Brazil.

\section{Materials and Methods}

To determine genetic variations on the isoflavone content of soybean genotypes, 233 Brazilian soybean cultivars were grown in Ponta Grossa, PR, Brazil (soybean season 2001/2002), in fertile soil (pH $\mathrm{CaCl}_{2}: 5.0, \mathrm{Al}: 0.0, \mathrm{~K}: 0.43, \mathrm{Ca}: 2.97, \mathrm{Mg}: 1.29$, and $\mathrm{H}+\mathrm{Al}: 10.45 \mathrm{cmol}_{\mathrm{c}} \mathrm{dm}^{-3}$; $\mathrm{C}: 22.75 \mathrm{~g} \mathrm{dm}^{-3}$; and $\left.\mathrm{P}=11.96 \mathrm{mg} \mathrm{dm}^{-3}\right)$.

For the evaluation of environmental effects on isoflavone composition, seed samples of five soybean cultivars grown in five northeastern municipalities, six cultivars grown in Minas Gerais state municipalities, and of seven cultivars grown in 19 southern municipalities, from Embrapa's uniform field tests, in Brazil (2001/2002 growing season) were analyzed. Isoflavone composition of 17 Embrapa soybean cultivars (BRS 133, BRS 184, BRS 185, BRS 212, BRS 213, BRS 214, BRS 215, BRS 230, BRS 231, BRS 232, BRS 257, BRS 258, BRS 259, BRS 260, BRS 261, BRS 262 and Embrapa 48) sown in Londrina, PR, in three dates (October, November and December) (2004/2005 soybean season), were also evaluated.

Seed lots from each location and cultivar were analyzed for isoflavone concentration. Seed samples were dried in an oven with forced air circulation at $50^{\circ} \mathrm{C}$ for three days, before grinding. Weighed samples of ground soybean were defatted overnight with hexane, then washed with three volumes of hexane and allowed to dry. The defatted samples were then extracted overnight with 4x DMSO:MeOH (1:1, volume:mass) at $50^{\circ} \mathrm{C}$. Sample extracts were centrifuged at $20,800 \mathrm{~g}$ for $15 \mathrm{~min}$ at $5^{\circ} \mathrm{C}$. After centrifugation, an aliquot of each sample was filtered through a $0.45-\mu \mathrm{m}$ Millipore filter into autoinjector vials for HPLC analysis.

The isoflavone concentrations were determined according to Berhow (2002) and Barnes et al. (1994) on an Agilent 1100 Series HPLC system equipped with a photodiode array detector system running under HP Chemstation software (A.06.01) (Agilent Technologies, Wilmington, DE, USA) and a $5-\mu \mathrm{m}$ particle size Inertsil ODS-3 C-18 reverse-phase column $(4.6 \times 250 \mathrm{~mm})$ (Metachem, Torrance, CA) with a Metaguard column (Metachem, Torrance, CA). The column was equilibrated with $20 \%$ methanol $(0.025 \%$ 
trifluroacetic acid $)$ and $80 \%$ water $(0.025 \%$ trifluroacetic

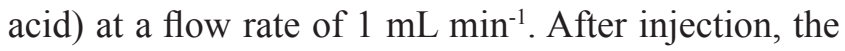
column was run for $2 \mathrm{~min}$ at the initial conditions, then developed with a linear gradient to $100 \%$ methanol $(0.025 \%$ trifluroacetic acid) over a period of $50 \mathrm{~min}$. The wavelength monitored and used for integration was of $285 \mathrm{~nm}$. Isoflavone peaks were identified by their spectra and retention time and confirmed by LC-MS. Standard curves were prepared with pure standards of daidzin, glycitin and genistin isolated at the National Center for Agricultural Utilization Research - NCAUR (USDA/ARS, USA). Molar extinction coefficients obtained from these curves were used to determine the levels of all forms of the isoflavones measured in the samples on a molar basis.

The multivariate statistics method was applied to the 233 soybean cultivars using a k-means partition cluster analysis (Souza, 2004) by means of the Statistica software, version 7.1 (Statsoft, 1995). For cluster analysis, each isoflavone content datum was standardized by subtracting the average value and dividing the result by the standard deviation. Differences in isoflavone content - daidzin, glycitin, genistin and acetylgenistin, the only forms found above detection limits in these samples - were evaluated in 233 cultivars by cluster analysis through the multivariate exploratory method of k-means (Andeberg, 1973). The method determines the greatest distance between any two cultivars at different clusters.

A completely randomized design was used to evaluate the experimental data from different planting locations. To determine significant differences among the mean values, ANOVA and Tukey tests at $5 \%$ probability were used for comparing data from cultivars and locations by using SAS (SAS Institute, 1995).

\section{Results and Discussion}

The 233 soybean cultivars were divided in nine groups according to their isoflavone contents (Table 1). The analysis of variance was significant $(\mathrm{p} \leq 0,000)$ for all the studied variables of the nine groups. The evaluation of the classified cultivar groups showed that the multivariate method was efficient in $94.4 \%$ of the cases. For each of the nine groups, cultivars were arranged as presented in Table 2 . The descriptive statistical analysis showed large variability for daidzin and genistin.

Daidzin and genistin were the major compounds observed in the analysis, which affected the total content of isoflavones. The highest values for total isoflavones were detected in groups nine, seven and two, represented by the following cultivars in decreasing order within the range of 461 to $200 \mathrm{mg} 100 \mathrm{~g} \mathrm{~g}^{-1}$ : CS 305, Embrapa 65, MG/BR-46, BRS 60, MS/ BRS 171, FT-15, FT-18, Tiaraju, Embrapa 59, MT/ BR-49, BRS 156, São Luiz, Emgopa 313, Mineira, Numbaíra, IAC 10 and MSBR 20. The lowest values in an increasing range from 12 to $100 \mathrm{mg}_{100 \mathrm{~g}^{-1} \text { were }}$ observed in cultivars Embrapa 48, Ocepar 19, IAS-3, BR-36, FT-13, CEP-16, FT-Iramaia, Ivorá, CEP-10, FT-Cometa, FT-9, Ivaí, Davis, Vila Rica, Ocepar 10, IAS-2, FT-Guaíra, Embrapa 58, Industrial, FT-16, Viçoja, BR-3, Pérola, Emgopa 302, Década, IAC-16, Embrapa 47, FT-20, BR-32, Bienville, Ocepar 17, SSP-S1, IAC-17, Ocepar-14. Cultivar Embrapa 48 showed the lowest concentration of total isoflavones (12 $\mathrm{mg} 100 \mathrm{~g}^{-1}$ ). This cultivar is preferred by food

Table 1. The nine groups with standardized data (average \pm standard deviation, and range of maximum and minimum values \pm standard deviation) of isoflavone concentrations ( $\mathrm{mg} 100 \mathrm{~g}^{-1}$ ) of 233 soybean cultivars defined by cluster analysis through the multivariate exploratory method of k-means.

\begin{tabular}{lrrrr}
\hline Groups & \multicolumn{1}{c}{ Daidzin } & Glycitin & Genistin & Acetylgenistin \\
\hline 1 & $135.3 \pm 0.52$ & $-65.8 \pm 0.61$ & $-33.5 \pm 0.68$ & $-131.8 \pm 0.28$ \\
2 & $60.0 \pm 0.86$ & $836.7 \pm 0.61$ & $118.7 \pm 2.37$ & $-40.1 \pm 0.15$ \\
3 & $-69.0 \pm 0.34$ & $-18.4 \pm 0.50$ & $-66.7 \pm 0.56$ & $-84.2 \pm 0.40$ \\
4 & $19.8 \pm 0.45$ & $-23.4 \pm 0.70$ & $102.3 \pm 0.56$ & $-114.5 \pm 0.36$ \\
5 & $-49.8 \pm 0.46$ & $0.33 \pm 0.38$ & $-81.5 \pm 0.51$ & $36.1 \pm 0.34$ \\
6 & $29.2 \pm 0.54$ & $-118.5 \pm 0.00$ & $46.6 \pm 0.80$ & $80.9 \pm 0.58$ \\
7 & $77.8 \pm 0.78$ & $70.7 \pm 0.38$ & $145.7 \pm 0.94$ & 26 \\
8 & $-19.5 \pm 0.39$ & $34.9 \pm 0.33$ & $37.7 \pm 0.44$ & $176.3 \pm 0.70$ \\
9 & $273.0 \pm 0.92$ & $-0.40 \pm 0.80$ & $119.8 \pm 0.96$ & $98.9 \pm 0.41$ \\
\hline Range & $-159-488 \pm 0.33$ & $-156-118 \pm 0.13$ & $-216-392 \pm 0.30$ & 14 \\
\hline
\end{tabular}


industries because of its mild flavor, which could be due to the low concentrations of isoflavones. These compounds are related to the astringency in soybean flavor. Cultivar BR-36 also presented low isoflavone concentration, which confirms the genetic effect observed in previous works (Carrão-Panizzi et al., 1995, 1998; Silva et al., 2009).

For daidzin, the highest average values were found in groups one, seven and nine, represented by cultivars IPB-T (138 mg $\left.100 \mathrm{~g}^{-1}\right)$, BRS 60 (145 mg $\left.100 \mathrm{~g}^{-1}\right)$ and FT-15 (165 mg $\left.100 \mathrm{~g}^{-1}\right)$. The lowest values for group eight were found in cv. CS 110 (29 mg $\left.100 \mathrm{~g}^{-1}\right)$, for group five in cv. Ocepar 19 (14 mg $\left.100 \mathrm{~g}^{-1}\right)$, and for group three in cv. Embrapa 48 (5 mg $\left.100 \mathrm{~g}^{-1}\right)$. Groups two (55-156 mg $100 \mathrm{~g}^{-1}$ ), seven (72-158 mg $100 \mathrm{~g}^{-1}$ ) and nine (77-188 mg $\left.100 \mathrm{~g}^{-1}\right)$ had the highest values for genistin, while groups five (6-7 mg $\left.100 \mathrm{~g}^{-1}\right)$, three (5-100 mg $100 \mathrm{~g}^{-1}$ ) and one (38-96 mg $100 \mathrm{~g}^{-1}$ ) had the lowest concentrations. For glycitin, an average of $18 \mathrm{mg} 100 \mathrm{~g}^{-1}$ was observed in all groups, except for group two, in which distinctive values for cultivars
BR-2 (127 mg $100 \mathrm{~g}^{-1}$ ) and Embrapa 65 (Itapoty) $\left(116 \mathrm{mg} 100 \mathrm{~g}^{-1}\right)$ were observed. Acetylgenistin was detected in lower concentration for all cultivars.

Isoflavones are highly affected by environmental conditions, as has already been observed in other soybean cultivars and in alternate growing locations (Tsukamoto et al., 1995; Carrão-Panizzi et al., 1998; Daydé et al., 2004). In Brazil, soybean is grown in locations within latitudes $32^{\circ} \mathrm{S}$ to $5^{\circ} \mathrm{N}$. This wide environmental range supports the need for further research aiming at determining location effects on isoflavone content of soybean seeds.

In the locations in the Northeast of Brazil (5$8^{\circ} \mathrm{S}$ ), the weather is very similar, with average temperatures of $27^{\circ} \mathrm{C}$ for the seed-filling period (February to April). Some variation in the local conditions (precipitation or temperature) could cause the differences in isoflavone concentrations among locations. No significant correlation was found between cultivars and locations for this region. However, in the municipalities of São Raimundo

Table 2. Soybean cultivars that compose each of the nine groups defined by cluster analysis.

\begin{tabular}{|c|c|}
\hline Group & Cultivars \\
\hline 1 & $\begin{array}{l}\text { IAC/PL-1, Embrapa 60, MS/BR-18 (Guavira), IAC-5, IPB-T, DM Soberana, IAC-2, CS 301, UFV-9 (Sucupira), BRS } 158 \\
\text { (Milena), BA/BR-31 (Bahia), MT/BRS } 63 \text { (Pintado), BR-15 (Mato Grosso) }\end{array}$ \\
\hline 2 & BR-2 and Embrapa 65 (Itapoty) \\
\hline 3 & $\begin{array}{l}\text { FT-Cometa, Paraná, CEP-12 (Cambará), FT-6 (Veneza), OCEPAR 3-Primavera, Pérola, Davis, IAC-17, FT-20 (Jaú), } \\
\text { OCEPAR 10, OCEPAR 5-Piquiri, CD-203, Embrapa 19, FT-Guairá, Ivorá, OCEPAR 6, Embrapa 58, CEP-10, CEP-16 } \\
\text { (Timbó), Embrapa 47, Embrapa 48, BR-38, MGBR-56 Confiança, Década, IAS-2, FT-Iramaia, União, FT-Líder, Campos } \\
\text { Gerais, BRS 138, BR-12, Embrapa } 4 \text { (BR-4 RC), Pampeira, OCEPAR 12, BR -32, MG/BR-22 (Garimpo), Ivaí, BR-23, IAS-3 } \\
\text { (Delta), FT-Abyara, BR-36, IAC-18, FT-Estrela, FT-14 (Piracema), Bienville, FT-17 (Bandeirantes), BR-40 (Itiquira), } \\
\text { Industrial, MS/BR-21 (Buriti), DM-Rainha, UFV-4, Santa Maria, Dourados, Embrapa 3, IAC Holambra Stwart 1, FT-440 }\end{array}$ \\
\hline 4 & $\begin{array}{l}\text { IAS-5, IAC-15, Embrapa } 45 \text { (Piratini), IAC -13, Bragg, BR-6 (Nova Bragg), EMGOPA } 309 \text { (Goiana), BR -14 (Modelo), BRS } \\
\text { 134, Embrapa } 64 \text { (Ponta Porã), FT -8 (Araucária), MS/BRS } 168 \text { (Piapara), RS -6 (Guassupi), IAC-12, MS/BRS } 170 \text { (Taquari), } \\
\text { Cobb, EMGOPA 304, Campeira, Embrapa 61, CS-201, BRS 157, MG/BR-58 (Segurança), Embrapa } 63 \text { (Mirador), Andrews, } \\
\text { BRS 135, FT-19 (Macacha), Embrapa } 2\end{array}$ \\
\hline 5 & $\begin{array}{l}\text { BR-24, OCEPAR 14, EMGOPA 302, CD-201, FT-Saray, FT-7 (Tarobá), FT-13 (Aliança), Lancer, OCEPAR 2, Iapó, FT-9 } \\
\text { (Inaê), Paranaíba, KI-S 602, CD-202, OCEPAR 17, FT-16, OCEPAR 8, BRS 132, OCEPAR 19-Cotia, OCEPAR 11, } \\
\text { IPAGRO-21, RS -7 (Jac uí), RS -9 (Itaúba), BR-4, IAC Foscarin-31,OCEPAR 18, KI-S 601, CEP-26 (Umbu), BRS 155, } \\
\text { Invicta, Sant'Ana, IAC-16, OCEPAR 4- Iguaçu, BR-29 (Londrina), IPAGRO-20, BR-30, BR-5, BR-3, BR-8 (Pelotas), } \\
\text { Missões, Sulina, SPS-1, FEPAGRO RS-10, Sertaneja, Hardee, Vila Rica, Viçoja, J-200, Paranagoiana, IAC-4, IAC-14, IAC-1, } \\
\text { UFV-15 (Uberlândia), EMGOPA } 311\end{array}$ \\
\hline 6 & $\begin{array}{l}\text { IAS-4, FT-12 (Nissei), BRS 137, Embrapa 26, Emgora } 315 \text { (Rio Vermelho), FT -10 (Princesa), MS/BR-18 (Pequi), MS/BR-59 } \\
\text { (Mandi), Santa Rosa, RS-5 (Esmeralda), FT-5 (Formosa), UFV-2, UFV-1, FT-102 }\end{array}$ \\
\hline 7 & $\begin{array}{l}\text { IAC-20, Embrapa 59, BR-156, São Luiz, BRS 136, OCEPAR 15- Paracatu, IAC-19, São Carlos, BRS 60, MG/BR-66 } \\
\text { (Liderança), IAC-10 }\end{array}$ \\
\hline 8 & $\begin{array}{l}\text { Planalto, SP/BR-41, Embrapa 5, Embrapa } 1 \text { (IAS-5RC), CEP-20 (Guajuvira), FT-Manacá, OCEPAR 7-Brilhante, FT-1, } \\
\text { FT-Eureka, BR-16, FT-3, Bossier, BRS 153, IAS -1, UFV-14 (Itamarati), UFV/ITM 1, CS 110, Embrapa 46, FT -2, KI-S 801, } \\
\text { BR-1, BR-37, OCEPAR-9 SS1, KI-S 702, Emgopa } 316 \text { (Rio Verde), OCEPAR 13, BR-13 (Maravilha), MG/BR-48 (Garimpo } \\
\text { RCH), Embrapa 62, MS/BR-20 (Ipê), Embrapa 25, MG/BR-54 (Renascença), BR-7, BRS 154, MS/BRS-169 (Bacuri), } \\
\text { OCEPAR-16, Embrapa 66, IAC-100, FT-4, BRS 133, FT-100, MS/BR-57 (Lambari), Embrapa } 32 \text { (Itaqui), MT/BR-50 (Parecis') }\end{array}$ \\
\hline$\overline{9}$ & $\begin{array}{l}\text { Mineira, Tiaraju, MS/BR -17 (São Gabriel), FT -15, MG/BR -42 (Kage), BRS 62, MS/BRS } 171 \text { (Campo Grande), FT-18 } \\
\text { (Xavante), MT/BR-49 (Pioneira), MG/BR-46 (Conquista), CS-305, EMGOPA 310, Numbaira, EMGOPA } 313 \text { (Anhanguera) }\end{array}$ \\
\hline
\end{tabular}


das Mangabeiras, MA, and Tasso Fragoso, MA, higher concentrations of total isoflavones were found for all cultivars (Table 3 ). In general, differences among cultivars were not remarkable in the Northeast, but cultivars BRS Sambaíba and BRS Tracajá showed the highest and lowest total average values for isoflavone content.

Growing locations in Minas Gerais, MG, in the Southeast region, are much closer to each other (only $18^{\circ}-19^{\circ} \mathrm{S}$ ), and all had an average temperature of $24^{\circ} \mathrm{C}$, and precipitation of about $400 \mathrm{~mm}$. Nevertheless, higher concentrations of isoflavones were observed in Sacramento, MG, for all cultivars (Table 4). Cultivar Preciosa had higher concentrations of isoflavones in all locations except for Uberlândia, MG.

In the South, with more weather variation among locations (Figure 1), all cultivars grown in Londrina and Palotina, PR, with higher average temperatures during the filling period $\left(26^{\circ} \mathrm{C}\right)$, showed reduced isoflavone concentrations. Higher concentrations of isoflavones were observed in Guarapuava, PR, and Campos Novos, SC, which had the lowest average temperatures $\left(21^{\circ} \mathrm{C}\right)$. Similar observations have encouraged nutriceutical-grade soybean production at locations in the South of Paraná state, where reduced average temperatures have resulted in increased isoflavone content (Carrão-Panizzi et al., 2003). Cultivars Codetec 202 and IAS-5 had the highest isoflavone concentrations (Figure 1). Cultivar IAS-5 showed higher concentrations of isoflavones in other studies, which suggests this may be a genetic trait (Carrão-Panizzi et al., 1999). The highest concentrations of isoflavones were observed for cultivars IAS-5 and BRS 66, grown in most of Rio Grande do Sul (Figure 2), where average temperatures are generally lower. Cultivars grown in these locations had higher isoflavone concentrations, except for soybeans grown in Seberi and São Luiz, RS, where warmer average temperatures were observed (Table 5).

Genetic variability in isoflavone concentration is observed when different soybean cultivars are grown in the same location. Of 12 different cultivars grown in Conquista, MG, cultivars BRS Piraíba and BRS Preciosa had the highest concentrations of isoflavones, while BRS Aurora, BRS Seleta, and BRS Pirarará had the lowest (Table 6). The concentrations of isoflavone aglycones (daidzein, glycitein and genistein) were either small or undetected, as expected for soybean seeds before processing. Malonyl and some acethyl forms of the isoflavones were not found in this study, because they were transformed to glycoside forms

Table 3. Total isoflavone (daidzin, genistin, glycitin, acetylgenistin, daidzein, genistein, glycitein) content (mg $\left.100 \mathrm{~g}^{-1}\right)$ in seeds of Brazilian soybean seed cultivars sown in different locations in the Northeast region of Brazil, in the 2001/2002 soybean season $^{(1)}$.

\begin{tabular}{|c|c|c|c|c|c|c|}
\hline Cultivars & $\begin{array}{c}\text { São Raimundo } \\
\text { das Mangabeiras }\end{array}$ & Rio do Coco & Bom Jesus & Sambaíba & Tasso Fragoso & Mean \\
\hline BRS Babaçu & 208 & 74 & 97 & 69 & 203 & 130B \\
\hline BRS Tracajá & 280 & 182 & 164 & 217 & 355 & $240 \mathrm{~A}$ \\
\hline BRS Sambaíba & 251 & 162 & 159 & 183 & 385 & $189 \mathrm{~A}$ \\
\hline BRS Seridó & 190 & 112 & 134 & 133 & 236 & 161B \\
\hline Cristalina & 150 & 130 & 145 & 155 & 243 & $165 \mathrm{~B}$ \\
\hline Mean & $232 b$ & $133 c$ & $139 \mathrm{c}$ & $151 \mathrm{c}$ & $284 a$ & \\
\hline
\end{tabular}

${ }^{(1)}$ Mean values followed by equal letters, small in the lines and capital in the columns, do not differ by the Tukey's test at $5 \%$ probability.

Table 4. Total isoflavone (daidzin, genistin, glycitin, acetylgenistin, daidzein, genistein, glycitein) content (mg $\left.100 \mathrm{~g}^{-1}\right)$ in seeds of Brazilian soybean cultivars sown in different locations of Minas Gerais state, Brazil, in the 2001/2002 soybean season $^{(1)}$.

\begin{tabular}{|c|c|c|c|c|c|}
\hline Cultivars & Uberaba & Conquista & Sacramento & Uberlândia & Mean \\
\hline EMGOPA 316 & $235 \mathrm{bAB}$ & $259 \mathrm{abAB}$ & $385 \mathrm{aA}$ & $312 \mathrm{abAB}$ & 298 \\
\hline BRS Seleta & $201 \mathrm{abB}$ & $116 \mathrm{cC}$ & $314 \mathrm{aA}$ & $126 \mathrm{bcC}$ & 189 \\
\hline MG/BR-46 Conquista & $287 \mathrm{abAB}$ & $187 \mathrm{bBC}$ & $412 \mathrm{aA}$ & $391 \mathrm{aA}$ & 319 \\
\hline BRS Apiakás & $185 \mathrm{bB}$ & $150 \mathrm{bBC}$ & $300 \mathrm{aA}$ & $302 \mathrm{aAB}$ & 235 \\
\hline Pintado & $198 \mathrm{abB}$ & $183 \mathrm{bBC}$ & $302 \mathrm{aA}$ & $187 \mathrm{bBC}$ & 217 \\
\hline$\underline{\text { BRS Preciosa }}$ & $358 \mathrm{aA}$ & $338 \mathrm{aA}$ & $453 \mathrm{aA}$ & $228 \mathrm{bB}$ & 344 \\
\hline Mean & 244 & 206 & 361 & 258 & \\
\hline
\end{tabular}

${ }^{(1)}$ Mean values followed by equal letters, small in the lines and capital in the columns, do not differ by the Tukey's test at $5 \%$ probability. 
during heat treatment, when seed samples were dried for three days at $50^{\circ} \mathrm{C}$ before grinding. Reduction of malonyl forms was also observed when soybean grains were soaked for 12 hours at $50^{\circ} \mathrm{C}$ (Carrão-Panizzi et al., 2003).

The evaluation of the soybean crops grown in Londrina, PR $\left(23^{\circ} 18^{\prime} \mathrm{S}\right)$, during the soybean season of $2004 / 2005$ showed differences in isoflavone content for crops initiated at three different planting dates

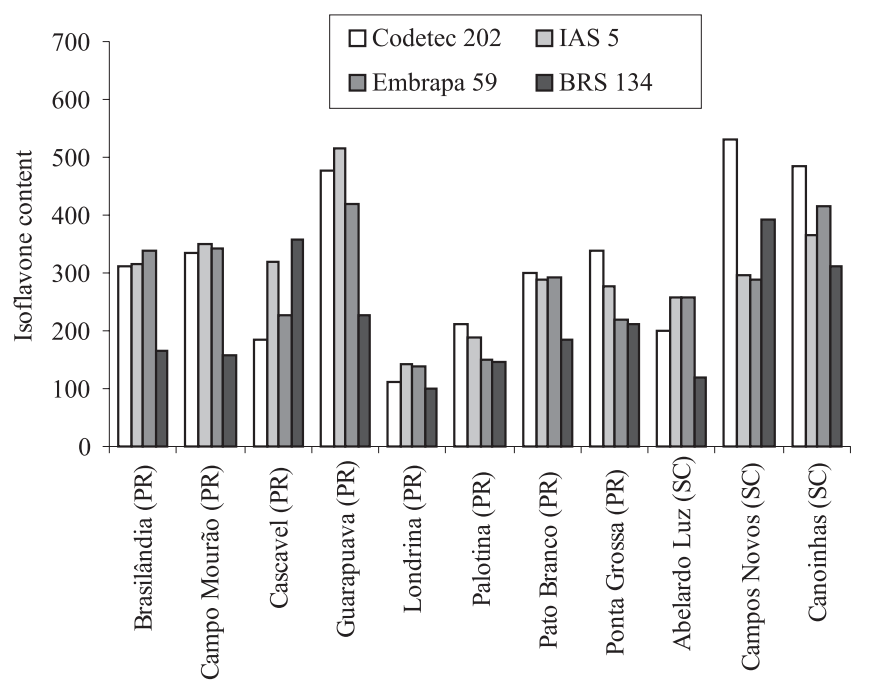

Figure 1. Total isoflavone(daidzin, genistin, glycitin, acetylgenistin, daidzein, genistein, and glycitein) content (mg $100 \mathrm{~g} \mathrm{~g}^{-1}$ ) in seeds of Brazilian soybean cultivars sown in different locations of the South region of Brazil, in Paraná (PR) and Santa Catarina (SC) states, in the 2001/2002 soybean season.
(October, November and December). The filling periods for the three crops were January, February and March respectively. The average temperatures and precipitations for these three crops were $23.4^{\circ} \mathrm{C}$ and $376 \mathrm{~mm}, 24.2^{\circ} \mathrm{C}$ and $52 \mathrm{~mm}$, and $24.5^{\circ} \mathrm{C}$ and $48 \mathrm{~mm}$ respectively (Brasil, 2007). All cultivars except BRS 262 yielded higher concentrations of isoflavones when sown in October (Table 7), with lower average temperatures and higher precipitation during the January seed-filling period. Adequate water supply and lower temperatures enhance isoflavone concentrations in the

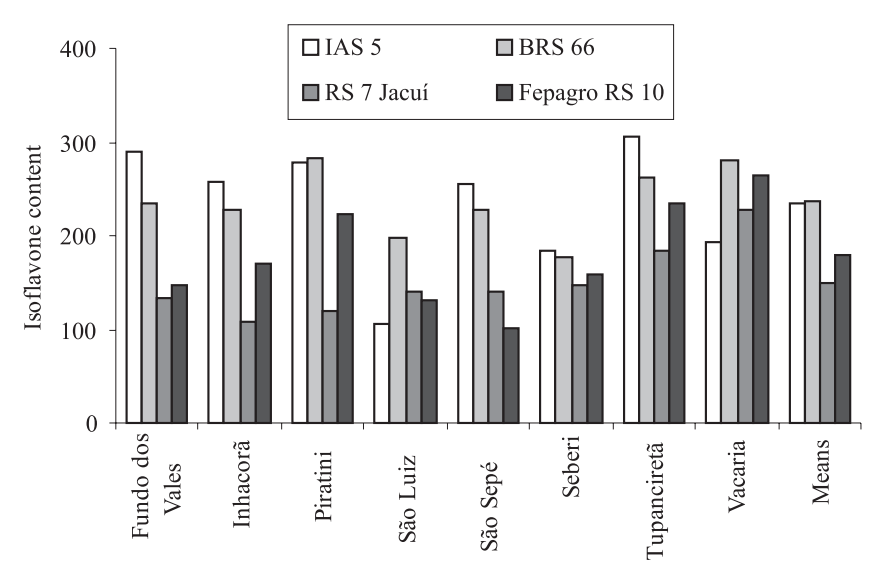

Figure 2. Total isoflavone (daidzin, genistin, glycitin, acetylgenistin, daidzein, genistein, glycitein) content (mg $100 \mathrm{~g}^{-1}$ ) in seeds of Brazilian soybean cultivars sown in Rio Grande do Sul (RS) state, in the South region of Brazil, in the $2001 / 2002$ soybean season.

Table 5. Environmental data of some of the locations in the South region of Brazil, in 2002.

\begin{tabular}{|c|c|c|c|c|c|}
\hline Locations $^{(3)}$ & Latitude & Longitude & Altitude (m) & $\begin{array}{c}\text { Average } \\
\text { temperature }{ }^{(1)}\left({ }^{\circ} \mathrm{C}\right)\end{array}$ & $\begin{array}{c}\text { Precipitation }^{(2)} \\
(\mathrm{mm})\end{array}$ \\
\hline Londrina, PR & $23^{\circ} 18^{\prime}$ & $51^{\circ} 09^{\prime}$ & 529 & 26.4 & 211 \\
\hline Cascavel, PR & $24^{\circ} 57^{\prime}$ & $53^{\circ} 27^{\prime}$ & 703 & 25.0 & 165 \\
\hline Palotina, PR & $24^{\circ} 16^{\prime}$ & $53^{\circ} 50^{\prime}$ & 322 & 26.4 & 63 \\
\hline Campo Mourão, PR & $24^{\circ} 02^{\prime}$ & $52^{\circ} 22^{\prime}$ & 572 & 24.8 & 106 \\
\hline Brasilândia, PR & $24^{\circ} 12^{\prime}$ & $53^{\circ} 38^{\prime}$ & 376 & - & - \\
\hline Ponta Grossa, PR & $25^{\circ} 05^{\prime}$ & $50^{\circ} 09^{\prime}$ & 859 & 22.4 & 313 \\
\hline Guarapuava, PR & $25^{\circ} 23^{\prime}$ & $51^{\circ} 27^{\prime}$ & 1,028 & 21.6 & 292 \\
\hline Pato Branco, PR & $26^{\circ} 13^{\prime}$ & $52^{\circ} 40^{\prime}$ & 831 & 23.1 & 282 \\
\hline Canoinhas, SC & $26^{\circ} 10^{\prime}$ & $50^{\circ} 23^{\prime}$ & 716 & - & - \\
\hline Abelardo Luz, SC & $26^{\circ} 34^{\prime}$ & $52^{\circ} 19^{\prime}$ & 775 & - & - \\
\hline Campos Novos, SC & $27^{\circ} 23^{\prime}$ & $51^{\circ} 13^{\prime}$ & 925 & 21.2 & 332 \\
\hline Seberi, RS & $27^{\circ} 28^{\prime}$ & $53^{\circ} 24^{\prime}$ & 546 & 26 & 177 \\
\hline Inhacorá, RS & $27^{\circ} 52^{\prime}$ & $54^{\circ} 01^{\prime}$ & 364 & - & - \\
\hline São Luiz, RS & $28^{\circ} 21^{\prime}$ & $51^{\circ} 33^{\prime}$ & 775 & 24.2 & 640 \\
\hline Vacaria, RS & $28^{\circ} 30^{\prime}$ & $50^{\circ} 56^{\prime}$ & 907 & 21.8 & 239 \\
\hline Tupanciretã, RS & $29^{\circ} 05^{\prime}$ & $53^{\circ} 50^{\prime}$ & 457 & - & - \\
\hline São Sepé, RS & $30^{\circ} 10^{\prime}$ & $53^{\circ} 34^{\prime}$ & 116 & 23.7 & 489 \\
\hline
\end{tabular}

${ }^{(1)}$ Average of daily minimal and maximal temperatures and ${ }^{(2)}$ total precipitation in the three months (February, March and April) in 2002 (Brasil, 2007). 
Table 6. Isoflavone content (mg $\left.100 \mathrm{~g}^{-1}\right)$ in seeds of Brazilian soybean cultivars sown in the region of Conquista, Minas Gerais state, Brazil, in the 2002 soybean season ${ }^{(1)}$.

\begin{tabular}{|c|c|c|c|c|c|c|c|c|}
\hline \multirow[t]{2}{*}{ Cultivar } & \multicolumn{7}{|c|}{ Isoflavones } & \multirow[t]{2}{*}{ Total } \\
\hline & Daidzin & Glycitin & Genistin & Acetylgenistin & Daidzein & Glycitein & Genistein & \\
\hline BRS Piraíba & $176 \mathrm{ab}$ & $29 a$ & $134 a$ & $14 \mathrm{a}$ & $6 a$ & $0 \mathrm{a}$ & $0 \mathrm{a}$ & $358 \mathrm{a}$ \\
\hline BRS Preciosa & $202 a$ & $15 \mathrm{a}$ & $118 \mathrm{ab}$ & $4 b$ & $5 \mathrm{ab}$ & $0 \mathrm{a}$ & $0 \mathrm{a}$ & $342 \mathrm{a}$ \\
\hline Emgopa 316 & $130 \mathrm{abc}$ & $18 \mathrm{a}$ & $111 \mathrm{ab}$ & $0 \mathrm{~b}$ & $5 \mathrm{ab}$ & $0 \mathrm{a}$ & $0 \mathrm{a}$ & $263 \mathrm{ab}$ \\
\hline BRS Garantia & $95 a b c$ & $20 \mathrm{a}$ & $91 \mathrm{ab}$ & $0 \mathrm{~b}$ & $4 a b$ & $0 \mathrm{a}$ & $0 \mathrm{a}$ & $210 \mathrm{ab}$ \\
\hline BRS Jiripoca & $102 \mathrm{abc}$ & $18 \mathrm{a}$ & $84 \mathrm{ab}$ & $0 \mathrm{~b}$ & $2 \mathrm{ab}$ & $0 \mathrm{a}$ & $0 \mathrm{a}$ & $205 \mathrm{ab}$ \\
\hline Conquista & $98 \mathrm{abc}$ & $10 \mathrm{a}$ & $73 \mathrm{ab}$ & $7 \mathrm{ab}$ & $3 a b$ & $0 \mathrm{a}$ & $0 \mathrm{a}$ & $190 \mathrm{ab}$ \\
\hline BRS Pintado & $89 a b c$ & $15 \mathrm{a}$ & $71 \mathrm{ab}$ & $8 \mathrm{ab}$ & $3 a b$ & $0 \mathrm{a}$ & $0 \mathrm{a}$ & $186 a b$ \\
\hline BRS Apiakás & $66 \mathrm{bc}$ & $10 \mathrm{a}$ & $64 a b$ & $11 \mathrm{ab}$ & $3 a b$ & $0 \mathrm{a}$ & $0 \mathrm{a}$ & $153 \mathrm{ab}$ \\
\hline BRS Gralha & $64 \mathrm{bc}$ & $19 \mathrm{a}$ & $62 \mathrm{ab}$ & $0 \mathrm{~b}$ & $1 \mathrm{ab}$ & $0 \mathrm{a}$ & $0 \mathrm{a}$ & $146 a b$ \\
\hline BRS Pirarará & $53 \mathrm{bc}$ & $21 \mathrm{a}$ & $58 \mathrm{ab}$ & $0 \mathrm{~b}$ & $4 a b$ & $0 \mathrm{a}$ & $0 \mathrm{a}$ & $135 \mathrm{ab}$ \\
\hline BRS Seleta & $38 \mathrm{c}$ & $16 \mathrm{a}$ & $51 \mathrm{ab}$ & $12 \mathrm{a}$ & $0.5 b$ & $0 \mathrm{a}$ & $0 \mathrm{a}$ & $117 \mathrm{ab}$ \\
\hline BRS Aurora & $34 \mathrm{c}$ & $16 \mathrm{a}$ & $39 b$ & $0 \mathrm{~b}$ & $0.5 b$ & $0 \mathrm{a}$ & $0 \mathrm{a}$ & $89 b$ \\
\hline Means & 96 & 17 & 80 & 5 & 3 & - & - & 200 \\
\hline
\end{tabular}

${ }^{(1)}$ Mean values followed by equal letters in the columns do not differ by the Tukey's test at $5 \%$ probability.

Table 7. Total isoflavones ( $\left.\mathrm{mg} 100 \mathrm{~g}^{-1}\right)$ in samples of soybean seeds from different cultivars sown in Londrina, PR $\left(23^{\circ} 18^{\prime} \mathrm{S}\right)$, in three different dates of the soybean season of 2004/2005.

\begin{tabular}{llccr}
\hline Cultivars & \multicolumn{3}{c}{ Sowing dates } & Average \\
\cline { 2 - 4 } & October & November & December & \\
\hline BRS 212 & $257.14 \mathrm{Aa}$ & $227.36 \mathrm{Ba}$ & $171.55 \mathrm{Ca}$ & 218.68 \\
BRS 133 & $219.09 \mathrm{Aa}$ & $160.81 \mathrm{Bd}$ & $137.56 \mathrm{Cd}$ & 172.49 \\
BRS 185 & $215.92 \mathrm{Ab}$ & $168.84 \mathrm{Bc}$ & $145.91 \mathrm{Cc}$ & 176.89 \\
BRS 260 & $206.08 \mathrm{Ac}$ & $181.69 \mathrm{Bb}$ & $108.52 \mathrm{Cf}$ & 165.43 \\
BRS 214 & $195.27 \mathrm{Ad}$ & $152.20 \mathrm{Ce}$ & $159.36 \mathrm{Bb}$ & 168.94 \\
BRS 261 & $193.22 \mathrm{Ad}$ & $118.02 \mathrm{Bgh}$ & $79.37 \mathrm{Ch}$ & 130.20 \\
BRS 213 & $191.63 \mathrm{Ad}$ & $145.18 \mathrm{Bef}$ & $104.90 \mathrm{Cf}$ & 147.24 \\
BRS 184 & $169.31 \mathrm{Ae}$ & $144.88 \mathrm{Bef}$ & $129.05 \mathrm{Ce}$ & 147.75 \\
BRS 259 & $150.03 \mathrm{Af}$ & $91.74 \mathrm{Ci}$ & $109.00 \mathrm{Bf}$ & 116.93 \\
BRS 215 & $146.86 \mathrm{Afg}$ & $90.60 \mathrm{Ci}$ & $123.36 \mathrm{Be}$ & 120.27 \\
Embrapa 48 & $143.95 \mathrm{Afg}$ & $73.50 \mathrm{Cj}$ & $91.89 \mathrm{Bg}$ & 103.11 \\
BRS 257 & $140.35 \mathrm{Ag}$ & $123.24 \mathrm{Bg}$ & $93.33 \mathrm{Cg}$ & 118.97 \\
BRS 232 & $120.87 \mathrm{Ah}$ & $66.13 \mathrm{Bjk}$ & $72.31 \mathrm{Bh}$ & 86.44 \\
BRS 231 & $120.61 \mathrm{Ah}$ & $113.49 \mathrm{Bh}$ & $90.06 \mathrm{Cg}$ & 108.05 \\
BRS 262 & $110.64 \mathrm{Ci}$ & $139.65 \mathrm{Bf}$ & $165.87 \mathrm{Aab}$ & 138.72 \\
BRS 230 & $81.56 \mathrm{Aj}$ & $62.34 \mathrm{Bk}$ & $56.47 \mathrm{Bi}$ & 66.79 \\
BRS 258 & $56.37 \mathrm{Ak}$ & $47.95 \mathrm{Bl}$ & $37.86 \mathrm{Cj}$ & 47.39 \\
\hline
\end{tabular}

${ }^{(1)}$ Means followed by equal letters, small in the lines and capital in the columns, do not differ by the Tukey's test at $5 \%$ probability.

mature beans (Daydé et al., 2004). The crops harvested from the November and December planting dates resulted in beans with lower isoflavone concentrations, which could be due to higher average temperatures $\left(24^{\circ} \mathrm{C}\right)$ and lower rainfall during the seed-filling period. Precipitation was sevenfold lower in February and March than in January. Cultivar BRS 262 has a much later maturation time, and the seed-filling period in all three planting times occurred during months of water shortage and higher mean temperature.

Daydé et al. (2004) also observed high heritability for isoflavone content and composition in the various cultivars they examined. Differences among genotypes in these experiments are consistent over time. For the experiment carried out in 2005, cultivar BRS $212 \mathrm{had}$ the highest concentration of total isoflavones for all the planting periods (218.68 $\left.\mathrm{mg} 100 \mathrm{~g}^{-1}\right)$, while cultivar BRS 258 had the lowest (47.39 mg $100 \mathrm{~g}^{-1}$ ). The lower concentration of isoflavone observed in BRS 258 must be a genetic character related to cultivar BR 36 , which also had lower isoflavone concentration in several other studies (Carrão-Panizzi et al., 1998). BRS 258 is derived from BR-36 improved for resistance to stem canker (Cultivares de soja 2008/2009 região Centro-Sul, 2007). Genetic expression of high or low isoflavone content manifests itself regardless of the environment, as observed in this experiment for the three different planting dates.

\section{Conclusions}

1. There are genetic differences for isoflavone contents among Brazilian soybean cultivars, and there is a good possibility of breeding for isoflavone content.

2. The highest values for total isoflavones are found in groups nine, seven and two, represented by the following cultivars, in decreasing order, within the

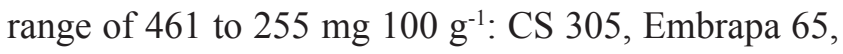


MG/BR-46, BRS 60, MS/BRS 171, FT-15, FT-18, Tiaraju, Embrapa 59, MT/BR- 49, BRS 156, São Luiz, Emgopa 313 e Mineira.

3. The lowest isoflavone content is observed in the following cultivars, in increasing order within the range of 12 to $100 \mathrm{mg} 100 \mathrm{~g}^{-1}$ : Embrapa 48, Ocepar 19, IAS-3, BR-36, FT-13, CEP-16, FT-Iramaia, Ivorá, CEP-10, FT-Cometa, FT-9, Ivaí, Davis, Vila Rica, Ocepar 10, IAS-2, FT-Guaíra, Embrapa 58, Industrial, FT-16, Viçoja, BR-3, Pérola, Emgopa 302, Década, IAC-16, Embrapa 47, FT-20, BR-32, Bienville, Ocepar 17, SSP-S1, IAC-17, Ocepar 14.

4. Differences in isoflavone content in different sowing locations permit the selection of locations for the production of soybean with low or high contents of isoflavones.

\section{References}

ANDEBERG, M.R. Cluster analysis for applications. New York: Academic Press, 1973. 359p.

BARNES, S.; KIRK, M.; COWARD, L. Isoflavones and their conjugates in soy foods: extraction conditions and analysis by HPLC-mass spectrometry. Journal of Agricultural and Food Chemistry, v.42, p.2466-2474, 1994.

BERHOW, M.A. Modern analytical techniques for flavonoid determination. In: BUSLIG, B.S.; MANTHEY, J.A. (Ed.). Flavonoids in the living cell. New York: Kluwer Academic, 2002. p.61-76.

BRASIL. Ministério da Agricultura, Pecuária e Abastecimento. Agritempo. 2007. Available at: <http://www.agritempo.gov.br/>. Accessed on: 25 Oct. 2009.

CARRÃO-PANIZZI, M.C. Avaliação de cultivares de soja quanto aos teores de isoflavonóides. Pesquisa Agropecuária Brasileira, v.31, p.691-698, 1996.

CARRÃO-PANIZZI, M.C.; BELÉIA, A. del P.; KITAMURA, K.; OLIVEIRA, M.C.N. Effects of genetics and environment on isoflavone content of soybean from different regions of Brazil. Pesquisa Agropecuária Brasileira, v.34, p.1787-1795, 1999.

CARRÃO-PANIZZI, M.C.; KITAMURA, K. Isoflavone content in Brazilian soybean cultivars. Breeding Science, v.45, p.295-300, 1995.

CARRÃO-PANIZZI, M.C.; KITAMURA, K.; BELÉIA, A. del P.; OLIVEIRA, M.C.N. Influence of growth locations on isoflavone contents in Brazilian soybean cultivars. Breeding Science, v.48, p.409-413, 1998.

CARRÃO-PANIZZI, M.C.; SIMÃO, A.S.; KIKUCHI, A. Efeitos de genótipos, ambientes e de tratamentos hidrotérmicos na concentração de isoflavonas agliconas em grãos de soja. Pesquisa Agropecuária Brasileira, v.38, p.897-902, 2003.
CULTIVARES de soja 2008/2009 região Centro-Sul. Londrina: Embrapa Soja: Fundação Meridional, 2008. 76p. (Embrapa Soja. Documentos, 309).

DAYDÉ, J.; BERGER, M.; THÉODOROU, V. Screening and breeding soybean for isoflavone content and composition. In: WORLD SOYBEAN RESEARCH CONFERENCE, 7.; INTERNATIONAL SOYBEAN PROCESSING AND UTILIZATION CONFERENCE, 4.; BRAZILIAN SOYBEAN CONGRESS, 3., 2004, Foz do Iguaçu. Proceedings. Londrina: Embrapa Soja, 2004. p.845-851.

GRAHAM, T.L. Flavonoid and isoflavonoid distribution in developing Soybean seedling tissues and in seed and root exudates. Plant Physiology, v.95, p.594-603, 1991.

KUDOU, S.; FLEURY, Y.; WELTI, D.; MAGNOLATO, D.; UCHIDA, T.; KITAMURA, K.; OKUBO, K. Malonyl isoflavone glycosides in soybean seeds (Glycine max (L.) Merril). Agricultural and Biological Chemistry, v.55, p.2227-2233, 1991.

MACLEOD, G.; AMES, J. Soy flavor and its improvement. CRC Critical Reviews in Food Science and Nutrition, v.27, p.219-400, 1988.

MESSINA, M.J. Legumes and soybeans: overview of their nutritional profiles and health effects. American Journal of Clinical Nutrition, v.70, p.439-450, 1999.

SAS INSTITUTE. SAS proprietary software release. Version 8.2. Cary: SAS Institute, 1995.

SILVA, J.B. da; CARRÃO-PANIZZI, M.C.; PRUDÊNCIO, S.H. Chemical and physical composition of grain-type and food-type soybean for food processing. Pesquisa Agropecuária Brasileira, v.44, p.777-784, 2009.

SOUZA, S.R. de. Classificação de variedades da soja quanto à concentração de isoflavonas utilizando análise estatística multivariada. Londrina: Universidade Estadual de Londrina, 2004. 71p.

STATSOFT. STATISTICA for Windows: computer program manual. Tulsa: Statsoft, 1995.

TSUKAMOTO, C.; KUDOU, S.; KUKUCHI, A; CARRÃO-PANIZZI, M.C.; ONO, T.; KITAMURA, K.; OKUBO, $\mathrm{K}$. Isoflavones in soybean products: composition, concentration and physiological effects. In: SIMPÓSIO BRASILEIRO SOBRE BENEFÍCIOS DA SOJA NA SAÚDE HUMANA, 1., 2001, Londrina. Anais. Londrina: Embrapa Soja, 2001. p.9-14. (Embrapa Soja. Documentos, 169).

TSUKAMOTO, C.; SHIMADA, S.; IGITA, K.; KUDOU, S.; KOKUBUN, M.; OKUBO, K.; KITAMURA, K. Factors affecting isoflavone content in soybean seeds: changes in isoflavones, saponins, and composition of fatty acids at different temperatures during seed development. Journal of Agricultural and Food Chemistry, v.43, p.1184-1192, 1995.

WANG, H.; MURPHY, P.A. Isoflavone composition of American and Japanese soybeans in Iowa: effects of variety, crop year and location. Journal of Agricultural and Food Chemistry, v.42, p.1674-1677, 1994.

Received on February 13, 2009 and accepted on September 20, 2009 